\title{
THE FIRST REPORT OF PRION-RELATED PROTEIN GENE (PRNT) POLYMORPHISMS IN GOAT
}

\author{
Yong-Chan $\mathrm{KIM}^{1,2}$ and Byung-Hoon JEONG ${ }^{1,2^{*}}$
}

${ }^{1}$ Korea Zoonosis Research Institute, Chonbuk National University, 820-120, Hana-ro, Iksan, Jeonbuk 570-390, Republic of Korea; ${ }^{2}$ Department of Bioactive Material Sciences, Chonbuk National University, Jeonju, Republic of Korea

(Received 22 December 2016; accepted 4 April 2017)

\begin{abstract}
Prion protein is encoded by the prion protein gene (PRNP). Polymorphisms of several members of the prion gene family have shown association with prion diseases in several species. Recent studies on a novel member of the prion gene family in rams have shown that prion-related protein gene (PRNT) has a linkage with codon 26 of prion-like protein (PRND). In a previous study, codon 26 polymorphism of $P R N D$ has shown connection with $P R N P$ haplotype which is strongly associated with scrapie vulnerability. In addition, the genotype of a single nucleotide polymorphism (SNP) at codon 26 of $P R N D$ is related to fertilisation capacity. These findings necessitate studies on the SNP of PRNT gene which is connected with $P R N D$. In goat, several polymorphism studies have been performed for $P R N P, P R N D$, and shadow of prion protein gene (SPRN). However, polymorphism on $P R N T$ has not been reported. Hence, the objective of this study was to determine the genotype and allelic distribution of SNPs of PRNT in 238 Korean native goats and compare PRNT DNA sequences between Korean native goats and several ruminant species. A total of five SNPs, including $P R N T$ c.-114G $>\mathrm{T}, P R N T$ c. $-58 \mathrm{~A}>\mathrm{G}$ in the upstream of PRNT gene, $P R N T$ c.71C $>\mathrm{T}$ (p.Ala24Val) and $P R N T$ c.102G $>\mathrm{A}$ in the open reading frame (ORF) and c.321C $>\mathrm{T}$ in the downstream of PRNT gene, were found in this study. All five SNPs of caprine $P R N T$ gene in Korean native goat are in complete linkage disequilibrium (LD) with a D' value of 1.0. Interestingly, comparative sequence analysis of the $P R N T$ gene revealed five mismatches between DNA sequences of Korean native goats and those of goats deposited in the GenBank. Korean native black goats also showed 5 mismatches in PRNT ORF with cattle. To the best of our knowledge, this is the first genetic research of the PRNT gene in goat.
\end{abstract}

Key words: Scrapie, fertility, goat, prion-related protein, single nucleotide polymorphism

"Corresponding author; E-mail: bhjeong@jbnu.ac.kr; Phone: 0082 (63) 900-4040, Fax: 0082 (63) 900-4012 
Prion diseases are characterised by the aggregation of abnormal prion protein $\left(\mathrm{PrP}^{\mathrm{Sc}}\right)$ and vacuolation in brain tissue (Prusiner, 1998). Prion disease in sheep and goat is called scrapie. It was first described in 1732 (Zabel and Reid, 2015). Scrapie does not seem to be transmissible to humans. Therefore, it had received relatively little attention for a long time (Wilson et al., 2012; Wadsworth et al., 2013). Recently, scrapie has received attention because of its association with bovine spongiform encephalopathy (BSE). Using scrapie-affected animals as feed has shown association with the progression of BSE (Wilesmith et al., 1988).

Prion protein gene (PRNP) is regarded as the main factor that confers susceptibility to scrapie. Sheep and goat have homologous genomic sequences of $P R N P$. Haplotypes of $P R N P$ codons 136, 154, and 171 are significantly associated with susceptibility to scrapie in sheep (Laplanche et al., 1993; Hunter et al., 1997a; Hunter et al., 1997b). Among several haplotypes, ARQ and ARR are well known for susceptible and resistant haplotypes, respectively (Greenlee et al., 2014; Greenlee et al., 2016). In goat, more than six polymorphisms in PRNP codons $142,143,146,154,211$, and 222 are associated with susceptibility to scrapie (Goldmann et al., 1996; Bouzalas et al., 2010; Ortiz-Pelaez et al., 2015; Srithayakumar et al., 2016). However, genetic association studies have not revealed susceptible haplotypes of $P R N P$ gene for scrapie in goat yet.

Recently, researchers have become interested in a novel member of the prion gene family called prion-related protein gene (PRNT). PRNT is testisspecific gene like prion-like protein gene (PRND) (Makrinou et al., 2002). A study has shown that the haplotype of PRNT is linked to codon 26 of PRND (Mesquita et al., 2016). In addition, previous studies indicated that codon 26 of $P R N D$ was linked to haplotypes ARQ, AHQ, and ARR of PRNP and fertilisation capacity (Pereira et al., 2009; Mesquita et al., 2010). Mesquita et al. (2010) have suggested that the haplotype of $P R N T$ might be associated with scrapie susceptibility and fertility in sheep. Therefore, the polymorphism study of PRNT is very important. However, the polymorphism of $P R N T$ in goat has not been reported yet. Furthermore, to the best of our knowledge, the sequence of the PRNT gene in Korean native black goat has not been described so far.

Therefore, the objective of this study was to determine the genotype, allele, and haplotype frequencies of caprine PRNT single nucleotide polymorphisms (SNPs) in 238 Korean native black goats and compare the DNA sequences of $P R N T$ gene between Korean native black goat and several ruminant species.

\section{Materials and methods}

\section{Genetic analysis}

Whole blood samples of Korean native black goats were obtained from a slaughterhouse in South Korea. Genomic DNA was isolated from $200 \mu$ of whole 
blood using QIAamp DNA blood Mini Kit (QIAGEN, Valencia, CA, USA). The coding region of caprine $P R N T$ gene was amplified using the primers PRNT-F (5'-TCGGCCTTGGTCTTTTCGTG-3') and PRNT-R (5'-GGCAACTTTGTA GTCCTCTCAAGT-3'). The total volume of each PCR mixture was $25 \mu \mathrm{l}$, including $1 \mu \mathrm{l}$ of genomic DNA, $0.5 \mu \mathrm{l}$ each of forward and reverse primers, $0.5 \mu \mathrm{l}$ of $10 \mathrm{mM}$ dNTP mixture, $0.5 \mu \mathrm{l}$ of $5 \times$ Taq DNA polymerase, and $2.5 \mu 1$ of $10 \times$ Taq DNA polymerase buffer (Promega, Madison, WI, USA). Thermal cycling was carried out at $95^{\circ} \mathrm{C}$ for 3 min for denaturation, followed by 35 cycles at $95^{\circ} \mathrm{C}$ for $30 \mathrm{sec}, 59^{\circ} \mathrm{C}$ for $30 \mathrm{sec}$, and $72{ }^{\circ} \mathrm{C}$ for $1 \mathrm{~min} 30 \mathrm{sec}$, and $1 \mathrm{cycle}$ at $72{ }^{\circ} \mathrm{C}$ for 4 min. The cycling program was established in an S-1000 Thermal Cycler (Bio-Rad Laboratories, Hercules, CA, USA). Purification of PCR products for sequencing was performed using the QIAquick ${ }^{\circledR}$ Gel Extraction Kit (QIAGEN, Valencia, CA, USA). PCR products were directly sequenced on an ABI 3730 Capillary Electrophoresis Sequencer (Applied Biosystems, Foster City, CA, USA) using Taq dideoxy terminator cycle sequencing kit (ABI) (Fig. 1). The amplicons were then analysed with the software Geospiza FinchTV Version 1.

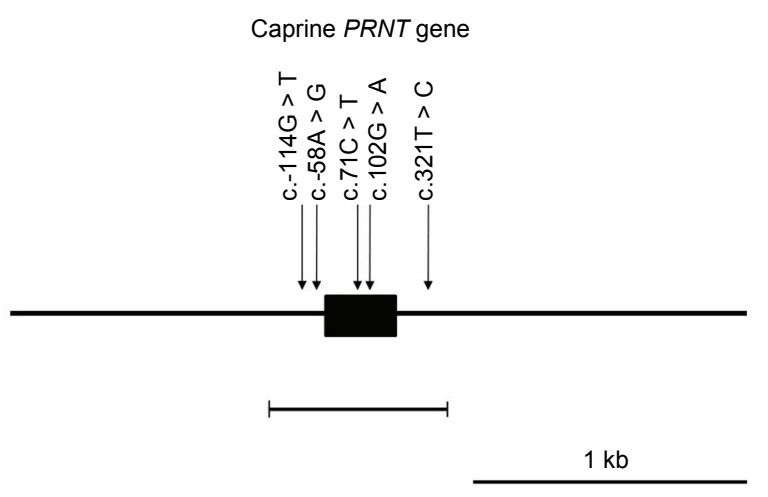

Fig. 1. Gene map and polymorphisms identified in the caprine PRNT gene. The open reading frame (ORF) within exon is marked by shaded block. Edged horizontal bar indicates sequenced region. The arrows indicate the five polymorphisms found in this study

\section{Statistical analyses}

Analyses of Linkage Disequilibrium (LD), haplotype, and Hardy-Weinberg Equilibrium (HWE) test in Korean native black goat were performed using SNP Analyzer $^{\mathrm{TM}} 2.0$ (http://snp.istech.info/istech/board/detail_snpa2.jsp).

\section{Sequence comparison}

Sequence alignment was performed using DNAStar analysis programs (DNAStar, Madison, WI, USA). Nucleic acid sequences of PRNT genes were obtained from GenBank at the National Center for Biotechnology Information 
(NCBI), including those of black goat, Korean native black goat, bighorn sheep Ovis canadensis (CP011898.1), domestic sheep Ovis aries (NM_001097649.1), domestic goat Capra hircus (AM412782.1), and domestic cow Bos taurus (DQ205538.1).

\section{Results}

The caprine PRNT gene is composed of one exon. To examine the genotype and allele frequencies of PRNT SNPs in Korean native black goat, we screened for SNPs within exon 1, including the open reading frame (ORF) of the caprine $P R N T$ gene in the genomic DNAs of 238 Korean native black goats. The following total five SNPs were found: $P R N T$ c. $-114 \mathrm{G}>\mathrm{T}, P R N T$ c. $-58 \mathrm{~A}>\mathrm{G}$ in the upstream of PRNT gene, PRNT c.71C $>\mathrm{T}$ and $P R N T$ c. $102 \mathrm{G}>\mathrm{A}$ in the ORF, and c.321C $>\mathrm{T}$ in the downstream of PRNT gene (Fig. 1). PRNT c.71C $>\mathrm{T}$ (p.Ala24Val) is a nonsynonymous SNPs. Of the 238 Korean native goats, 89 $(37.39 \%)$ were homozygous of C, 34 (14.29\%) were homozygous of T, and 115 $(48.32 \%)$ were heterozygous. The genotype frequencies of these five SNPs were in the HWE in Korean native goats (Table 1).

To examine whether there was a strong LD among the five SNPs, LD coefficient $\left(\left|\mathrm{D}^{\prime}\right|\right)$ was calculated in these SNPs of Korean native black goat. All five SNPs of the caprine PRNT gene in Korean native goat were in complete LD with a D' value of 1.0 (Table 2).

Analysis of haplotype frequency was carried out for Korean native black goat. As shown in Table 3, four different haplotypes existed in the caprine PRNT polymorphisms. Among the four haplotypes, the haplotype TGTGC had the highest frequency $(38.5 \%)$.

Table 1

Genotype and allele frequencies of $P R N T$ polymorphisms in Korean native black goats

\begin{tabular}{lcccccc}
\hline & \multicolumn{3}{c}{$\begin{array}{c}\text { Genotype frequency, } \\
\mathrm{n}(\%)\end{array}$} & \multicolumn{2}{c}{$\begin{array}{c}\text { Allele frequency, } \\
\mathrm{n}(\%)\end{array}$} & HWE \\
\hline c.-114G $>\mathrm{T}$ & $\mathrm{GG}$ & $\mathrm{GT}$ & $\mathrm{TT}$ & $\mathrm{G}$ & $\mathrm{T}$ & \\
& $60(25.21)$ & $123(51.68)$ & $55(23.11)$ & $243(51.05)$ & $233(48.95)$ & 0.5992 \\
c. $-58 \mathrm{~A}>\mathrm{G}$ & $\mathrm{AA}$ & $\mathrm{AG}$ & $\mathrm{GG}$ & $\mathrm{A}$ & $\mathrm{G}$ & \\
& $60(25.21)$ & $123(51.68)$ & $55(23.11)$ & $243(51.05)$ & $233(48.95)$ & 0.5992 \\
c.71C $>\mathrm{T}$ & $\mathrm{CC}$ & $\mathrm{CT}$ & $\mathrm{TT}$ & $\mathrm{C}$ & $\mathrm{T}$ & \\
& $89(37.39)$ & $115(48.32)$ & $34(14.29)$ & $293(61.55)$ & $183(38.45)$ & 0.7470 \\
c.102G $>\mathrm{A}$ & $\mathrm{GG}$ & $\mathrm{GA}$ & $\mathrm{AA}$ & $\mathrm{G}$ & $\mathrm{A}$ & \\
& $191(80.25)$ & $45(18.91)$ & $2(0.84)$ & $427(89.71)$ & $49(10.29)$ & 0.7140 \\
c.321C $>\mathrm{T}$ & $\mathrm{CC}$ & $\mathrm{CT}$ & $\mathrm{TT}$ & $\mathrm{C}$ & $\mathrm{T}$ & \\
& $101(42.44)$ & $103(43.28)$ & $34(14.28)$ & $305(64.08)$ & $171(35.92)$ & 0.3550
\end{tabular}


Table 2

Linkage disequilibrium (LD) among five single nucleotide polymorphisms (SNPs) of the PRNT gene in Korean native black goats

\begin{tabular}{|c|c|c|c|c|c|}
\hline & c. $-114 \mathrm{G}>\mathrm{T}$ & c. $-58 \mathrm{~A}>\mathrm{G}$ & c. $71 \mathrm{C}>\mathrm{T}$ & c. $102 \mathrm{G}>\mathrm{A}$ & c. $321 \mathrm{C}>\mathrm{T}$ \\
\hline c. $-114 \mathrm{G}>\mathrm{T}$ & - & 1.0 & 1.0 & 1.0 & 1.0 \\
\hline c. $-58 \mathrm{~A}>\mathrm{G}$ & - & - & 1.0 & 1.0 & 1.0 \\
\hline c. $71 \mathrm{C}>\mathrm{T}$ & - & - & - & 1.0 & 1.0 \\
\hline c. $102 \mathrm{G}>\mathrm{A}$ & - & - & - & - & 1.0 \\
\hline c. $321 \mathrm{C}>\mathrm{T}$ & - & - & - & - & - \\
\hline
\end{tabular}

Table 3

Haplotype frequencies of the five $P R N T$ polymorphisms in Korean native black goats

\begin{tabular}{lc}
\hline Haplotype & $\begin{array}{c}\text { Korean native black goats } \\
(\mathrm{n}=238)\end{array}$ \\
\hline TGTGC & $183(0.385)$ \\
GACGT & $171(0.359)$ \\
GACGC & $72(0.151)$ \\
TGCAC & $49(0.103)$ \\
\hline
\end{tabular}

To compare nucleotide sequences of $P R N T$ genes in Korean native goat, Ovis canadensis, Ovis aries, Capra hircus, and Bos taurus, we performed multiple sequence alignment using DNAStar. The nucleotide sequence of PRNT gene of Korean native goat had the highest sequence identities (100\%) with the PRNT gene of Ovis canadensis, followed by that of Ovis aries (99\%), Capra hircus (97\%) and Bos taurus (97\%) (Fig. 2). Notably, the DNA sequence of the PRNT gene in Korean native goat had five mismatches with the caprine PRNT sequence deposited in GenBank.

\section{Discussion}

There are a lot of controversies about the novel member of the prion gene family $P R N T$, especially as to whether the ruminant $P R N T$ is a pseudogene. When the ruminant $P R N T$ gene is compared to the human PRNT gene, the PRNT gene is truncated. Therefore, the PRNT gene has been regarded as a pseudogene (Choi et al., 2006; Premzl and Gamulin, 2007). However, recent studies have confirmed the translation of $P R N T$ gene in ram and goat. In addition, Prt, encoded by the PRNT gene, has been detected at the acrosome region of spermatozoa (Pimenta et al., 2012).

Previous studies have revealed three members (PRNP, PRND, and PRNT) of the prion gene family showing linkage with SNPs in sheep (Pereira et al., 2009; 


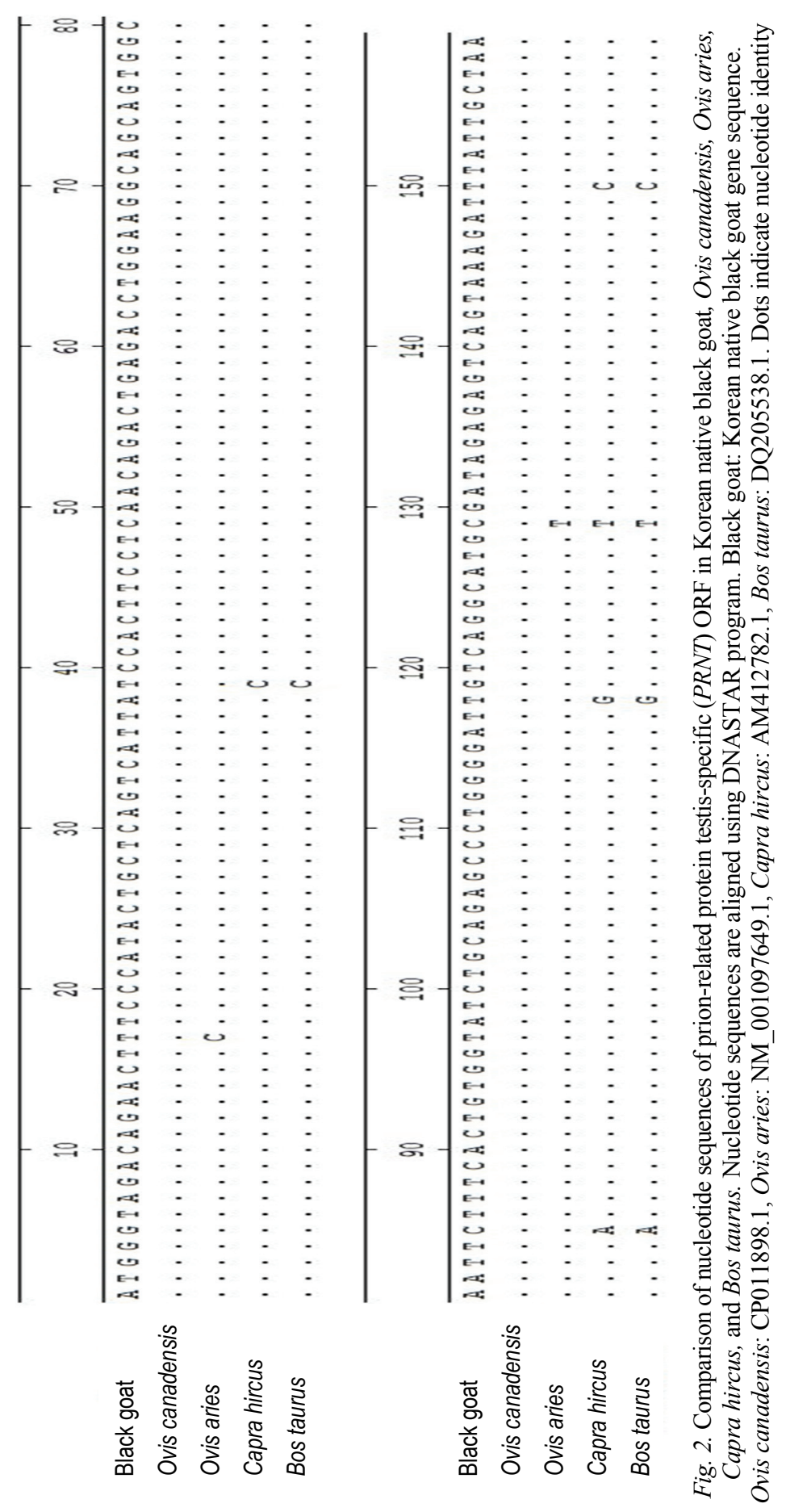


Mesquita et al., 2010; Mesquita et al., 2016). The G allele at codon 26 of PRND showed a strong LD with the ARR haplotype of PRNP. The ARR haplotype can confer resistance to scrapie. In addition, the A allele at codon 26 of $P R N D$ was remarkably linked to the ARQ and AHQ haplotypes of PRNP. Both ARQ and AHQ haplotypes are associated with susceptibility to scrapie. That is, codon 26 of the $P R N D$ gene represents susceptibility to scrapie through strong LD. Interestingly, $P R N D$ genotypes GG, GA, and AA were linked to the haplotype of $P R N T$. Since the genotype at codon 26 of $P R N D$ was associated with the sperm capacitation process, improving sperm cryoresistance and embryo production (Ferreira et al., 2016), the haplotype of $P R N T$ represents sperm fertility. It has been shown that Doppel encoded by $P R N D$ is significantly associated with male fertilisation. Ablation of $P R N D$ has resulted in sterility and malformed spermatozoa (Behrens et al., 2002; Paisley et al., 2004). However, since the genetic variation of $P R N D$ codon 26 is a synonymous SNP, further studies are needed to understand its influence on fertilisation.

Association studies between prion diseases and PRNT polymorphisms have not been performed yet. Except for $P R N T$, association studies on prion diseases with polymorphisms of other members of the prion gene family have been well conducted. As a gene with testis-specific expression, a functional study of PRNT SNPs should be performed to assess its relationship with fertility in the future.

Our sequence alignment analysis revealed five mismatches between the DNA sequence of Korean native goat and that of goat deposited at GenBank. Scrapie has not been reported in Korean native black goat thus far. Therefore, these differences in the sequence of $P R N T$ might have some significance. A previous study has shown that the caprine $P R N T$ sequence shared $100 \%$ sequence identities with that of cattle (Kocer et al., 2007). However, the PRNT sequence of Korean native black goat also had five mismatches with the PRNT ORF of cattle. Korean native goat shared $99 \%$ sequence identities with sheep PRNT. Sequence alignment is a way of arranging sequences of DNA, RNA, or protein to identify regions of similarity that might have functional, structural, or evolutionary relationships among the sequences (Lagares et al., 2016). Our results suggest that the PRNT of Korean native goat is evolutionally close to that of sheep.

We found five SNPs in the ORF and nascent region of the caprine PRNT gene. One SNP was nonsynonymous. In our previous studies, the distribution of $P R N P$ and PRND SNPs has shown remarkable difference between Koreans and Europeans (Jeong et al., 2004; Jeong et al., 2005a; Jeong et al., 2005b). In addition, the genotype and allele frequencies of polymorphisms of the PRNP gene are significantly different between Hanwoo and dairy cattle (Jeong et al., 2005c; Jeong et al., 2006; Jeong et al., 2013). Furthermore, our previous study in cattle has revealed that the PRNT ORF region is non-polymorphic. Previous studies have also indicated that the bovine $P R N T$ sequence is $100 \%$ homologous with the goat PRNT sequence. Therefore, SNPs might not exist in the ORF and nas- 
cent region of the caprine $P R N T$. However, we also obtained a similar result with data in sheep. Pereira et al. (2009) have reported that sheep have four polymorphisms in the PRNT ORF region, including two nonsynonymous SNPs (Mesquita et al., 2016). This highly polymorphic propensity showed coincidence with sequence homology between sheep and Korean native goat.

Since PRNT is absent in rodents, functional studies of different SNPs in highly homologous sequences of ram and goat $P R N T$ will be very useful in the future. To the best of our knowledge, this is the first study that reports the polymorphism of $P R N T$ in goat.

\section{Acknowledgements}

This research was supported by the Basic Science Program through the National Research Foundation of Korea (NRF) funded by the Ministry of Education, Science and Technology (2015R1D1A1A010599). Mr. Y.-C. Kim was supported by the BK21 Plus Program in the Department of Bioactive Material Sciences.

\section{References}

Behrens, A., Genoud, N., Naumann, H., Rulicke, T., Janett, F., Heppner, F. L., Ledermann, B. and Aguzzi, A. (2002): Absence of the prion protein homologue Doppel causes male sterility. EMBO J. 21, 3652-3658.

Bouzalas, I. G., Dovas, C. I., Banos, G., Papanastasopoulou, M., Kritas, S., Oevermann, A., Papakostaki, D., Evangelia, C., Papadopoulos, O., Seuberlich, T. and Koptopoulos, G. (2010): Caprine PRNP polymorphisms at codons 171, 211, 222 and 240 in a Greek herd and their association with classical scrapie. J. Gen. Virol. 91, 1629-1634.

Choi, S. H., Kim, I. C., Kim, D. S., Kim, D. W., Chae, S. H., Choi, H. H., Choi, I., Yeo, J. S., Song, M. N. and Park, H. S. (2006): Comparative genomic organization of the human and bovine PRNP locus. Genomics 87, 598-607.

Ferreira, L. M., Garcia-Herreros, M., Domingos, A., Marques, C. C., Mesquita, P., Barbas, J. P., Baptista, M. C., Pimenta, J., Horta, A. E., Prates, J. A. and Pereira, R. M. (2016): Prion protein 2 (dublet) gene $(P R N D)$ : role in ovine semen capacitation, cryopreservation and fertility. Reprod. Fertil. Dev. April 2016. doi: 10.1071/RD15214. [Epub ahead of print].

Goldmann, W., Martin, T., Foster, J., Hughes, S., Smith, G., Hughes, K., Dawson, M. and Hunter, N. (1996): Novel polymorphisms in the caprine $\operatorname{Pr} P$ gene: a codon 142 mutation associated with scrapie incubation period. J. Gen. Virol. 77, 2885-2891.

Greenlee, J. J., Kunkle, R. A., Richt, J. A., Nicholson, E. M. and Hamir, A. N. (2014): Lack of prion accumulation in lymphoid tissues of PRNP ARQ/ARR sheep intracranially inoculated with the agent of scrapie. PloS One 9, e108029.

Greenlee, J. J., Smith, J. D. and Hamir, A. N. (2016): Oral inoculation of neonatal Suffolk sheep with the agent of classical scrapie results in $\operatorname{PrP}(\mathrm{Sc})$ accumulation in sheep with the PRNP ARQ/ARQ but not the ARQ/ARR genotype. Res. Vet. Sci. 105, 188-191.

Hunter, N., Goldmann, W., Foster, J. D., Cairns, D. and Smith, G. (1997a): Natural scrapie and PrP genotype: case-control studies in British sheep. Vet. Rec. 141, 137-140.

Hunter, N., Moore, L., Hosie, B. D., Dingwall, W. S. and Greig, A. (1997b): Association between natural scrapie and PrP genotype in a flock of Suffolk sheep in Scotland. Vet. Rec. 140, $59-63$. 
Jeong, B. H., Jin, H. T., Carp, R. I. and Kim, Y. S. (2013): Bovine spongiform encephalopathy (BSE)-associated polymorphisms of the prion protein $(P R N P)$ gene in Korean native cattle. Anim. Genet. 44, 356-357.

Jeong, B. H., Kim, N. H., Choi, E. K., Lee, C., Song, Y. H., Kim, J. I., Carp, R. I. and Kim, Y. S. (2005a): Polymorphism at 3' UTR +28 of the prion-like protein gene is associated with sporadic Creutzfeldt-Jakob disease. Eur. J. Hum. Genet. 13, 1094-1097.

Jeong, B. H., Lee, K. H., Kim, N. H., Jin, J. K., Kim, J. I., Carp, R. I. and Kim, Y. S. (2005b): Association of sporadic Creutzfeldt-Jakob disease with homozygous genotypes at PRNP codons 129 and 219 in the Korean population. Neurogenetics 6, 229-232.

Jeong, B. H., Lee, Y. J., Kim, N. H., Carp, R. I. and Kim, Y. S. (2006): Genotype distribution of the prion protein gene $(P R N P)$ promoter polymorphisms in Korean cattle. Genome 49, $1539-1544$.

Jeong, B. H., Nam, J. H., Lee, Y. J., Lee, K. H., Jang, M. K., Carp, R. I., Lee, H. D., Ju, Y. R., Ahn Jo, S., Park, K. Y. and Kim, Y. S. (2004): Polymorphisms of the prion protein gene $(P R N P)$ in a Korean population. J. Hum. Genet. 49, 319-324.

Jeong, B. H., Sohn, H. J., Lee, J. O., Kim, N. H., Kim, J. I., Lee, S. Y., Cho, I. S., Joo, Y. S., Carp, R. I. and Kim, Y. S. (2005c): Polymorphisms of the prion protein gene (PRNP) in Hanwoo (Bos taurus coreanae) and Holstein cattle. Genes Genet. Syst. 80, 303-308.

Kocer, A., Gallozzi, M., Renault, L., Tilly, G., Pinheiro, I., Le Provost, F., Pailhoux, E. and Vilotte, J. L. (2007): Goat $P R N D$ expression pattern suggests its involvement in early sex differentiation. Dev. Dyn. 236, 836-842.

Lagares, A., Roux, I. and Valverde, C. (2016): Phylogenetic distribution and evolutionary pattern of an $\alpha$-proteobacterial small RNA gene that controls polyhydroxybutyrate accumulation in Sinorhizobium meliloti. Mol. Phylogenet. Evol. 99, 182-193.

Laplanche, J. L., Chatelain, J., Westaway, D., Thomas, S., Dussaucy, M., Brugere-Picoux, J. and Launay, J. M. (1993): $\operatorname{Pr} P$ polymorphisms associated with natural scrapie discovered by denaturing gradient gel electrophoresis. Genomics 15, 30-37.

Makrinou, E., Collinge, J. and Antoniou, M. (2002): Genomic characterization of the human prion protein $(\operatorname{Pr} P)$ gene locus. Mamm. Genome. 13, 696-703.

Mesquita, P., Batista, M., Marques, M. R., Santos, I. C., Pimenta, J., Silva Pereira, M., Carolino, I., Santos Silva, F., Oliveira Sousa, M. C., Gama, L. T., Fontes, C. M., Horta, A. E., Prates, J. A. and Pereira, R. M. (2010): Prion-like Doppel gene polymorphisms and scrapie susceptibility in Portuguese sheep breeds. Anim. Genet. 41, 311-314.

Mesquita, P., Garcia, V., Marques, M. R., Santos Silva, F., Oliveira Sousa, M. C., Carolino, I., Pimenta, J., Fontes, C. M., Horta, A. E., Prates, J. A. and Pereira, R. M. (2016): The prionrelated protein (testis-specific) gene (PRNT) is highly polymorphic in Portuguese sheep. Anim. Genet. 47, 128-132.

Ortiz-Pelaez, A., Georgiadou, S., Simmons, M. M., Windl, O., Dawson, M., Arnold, M. E., Neocleous, P. and Papasavva-Stylianou, P. (2015): Allelic variants at codon 146 in the PRNP gene show significant differences in the risk for natural scrapie in Cypriot goats. Epidemiol. Infect. 143, 1304-1310.

Paisley, D., Banks, S., Selfridge, J., McLennan, N. F., Ritchie, A. M., McEwan, C., Irvine, D. S., Saunders, P. T., Manson, J. C. and Melton, D. W. (2004): Male infertility and DNA damage in Doppel knockout and prion protein/Doppel double-knockout mice. Am. J. Pathol. 164, 2279-2288.

Pereira, R. M., Mesquita, P., Batista, M., Baptista, M. C., Barbas, J. P., Pimenta, J., Santos, I. C., Marques, M. R., Vasques, M. I., Silva Pereira, M., Santos Silva, F., Oliveira Sousa, M. C., Fontes, C. M., Horta, A. E., Prates, J. A. and Marques, C. C. (2009): Doppel gene polymorphisms in Portuguese sheep breeds: insights on ram fertility. Anim. Reprod. Sci. 114, $157-166$.

Pimenta, J., Domingos, A., Santos, P., Marques, C. C., Cantante, C., Santos, A., Barbas, J. P., Baptista, M. C., Horta, A. E., Viegas, A., Mesquita, P., Goncalves, J., Fontes, C. A., Prates, J. 
A. and Pereira, R. M.. (2012): Is PRNT a pseudogene? Identification of ram Prt in testis and ejaculated spermatozoa. PloS One 7, e42957.

Premzl, M. and Gamulin, V. (2007): Comparative genomic analysis of prion genes. BMC Genomics 8, 1.

Prusiner, S. B. (1998): Prions. Proc. Natl. Acad. Sci. U S A 95, 13363-13383.

Srithayakumar, V., Mitchell, G. B. and White, B. N. (2016): Identification of amino acid variation in the prion protein associated with classical scrapie in Canadian dairy goats. BMC Vet. Res. 12, 59.

Wadsworth, J. D., Joiner, S., Linehan, J. M., Balkema-Buschmann, A., Spiropoulos, J., Simmons, M. M., Griffiths, P. C., Groschup, M. H., Hope, J., Brandner, S., Asante, E. A. and Collinge, J. (2013): Atypical scrapie prions from sheep and lack of disease in transgenic mice overexpressing human prion protein. Emerg. Infect. Dis. 19, 1731-1739.

Wilesmith, J. W., Wells, G. A., Cranwell, M. P. and Ryan, J. B. (1988): Bovine spongiform encephalopathy: epidemiological studies. Vet. Rec. 123, 638-644.

Wilson, R., Plinston, C., Hunter, N., Casalone, C., Corona, C., Tagliavini, F., Suardi, S., Ruggerone, M., Moda, F., Graziano, S., Sbriccoli, M., Cardone, F., Pocchiari, M., Ingrosso, L., Baron, T., Richt, J., Andreoletti, O., Simmons, M., Lockey, R., Manson, J. C. and Barron, R. M. (2012): Chronic wasting disease and atypical forms of bovine spongiform encephalopathy and scrapie are not transmissible to mice expressing wild-type levels of human prion protein. J. Gen. Virol. 93, 1624-1629.

Zabel, M. D. and Reid, C. (2015): A brief history of prions. Pathog. Dis. 73, ftv087. 